\title{
The role of spatial visual analysis in historical religious studies
}

ADAM MERTEL ${ }^{1}$, ZDENĚK STACHOŇ $^{1}$, TOMÁŠ GLOMB ${ }^{2}$, TOMÁŠ HAMPEJS ${ }^{2}$, VOJTĚCH KAŠE ${ }^{2}$, ALEŠ CHALUPA ${ }^{2}$, DALIBOR PAPOUŠEK ${ }^{2}$

1 Masaryk University, Faculty of Science, Department of Geography, Brno, Czechia; e-mail: zstachon@geogr.muni.cz

${ }^{2}$ Masaryk University, Faculty of Arts, Department for the Study of Religions, Brno, Czechia

ABSTRACT This paper examines the possibilities and benefits of spatial visual analysis in exploring and answering a hypothesis proposed in a historical study of religions. The content was based on the GEHIR project, which studies the history of ancient Graeco-Roman religions using innovative methods applied in the study of complex systems. The first part of the paper describes three case studies and their hypotheses and input datasets. Relevant spatial methods are subsequently proposed and were implemented as a web-based map application deployed online (gehir.phil.muni.cz/map). Apart from certain constraints, the new option and benefit of using visual analysis brings a unique view to phenomena in historical research. This could open new discussions and contribute to the dissemination of geographic methods to, and overall knowledge of, historians.

KEY WORDS geographic visualization - spatial analysis - study of religions - web maps

MERTEL, A., STACHOŇ, Z., GLOMB, T., HAMPEJS, T., KAŠE, V., CHALUPA, A., PAPOUŠEK, D. (2019): The role of spatial visual analysis in historical religious studies. Geografie, 124, 3, 265-280. Received August 2018, accepted April 2019.

(C) Česká geografická společnost, z. s., 2019 


\section{Introduction}

The concept of digital humanities (described, for example, in Schreibman, Siemens, Unsworth (2008), Presner (2010), and Hayles (2011), as the use of computational tools and methods in traditional humanities disciplines) is rising in popularity. With these new methods and technologies, researchers can present new findings and outputs in unique form (Berry 2012, Gold 2012, and others). The GEHIR project - Generative Historiography of the Ancient Mediterranean - also falls under this new wave of orientation in interdisciplinary research based on technological innovation. While the project applies a variety of innovative methods used in studying the dynamics of complex systems (mathematical and computational modelling, network science) to the historiography of ancient Graeco-Roman religions (more at gehir.phil.muni.cz), its research output was especially productive because of spatial analysis tools rooted in the methods of geography and GIScience.

These methods are employed in various scientific disciplines; however, combined studies are emerging in humanities fields, providing the opportunity for narrower definitions and focus using the concept of spatial humanities (see Bodenhamer, Corrigan, Harris, eds. 2010) or Historical GIS (see Gregory, Gedes 2014). This study specifically explored the concept of spatial analysis (a combination of automated analysis and interactive visualisation for effective understanding, reasoning and decision-making; Keim et al. 2008) and its hypothesis-driven research potential for studying ancient religious history in the GEHIR Project's case studies.

\subsection{Motivation}

As previously mentioned, geography and GIScience (GIS) provide several methods and tools that can be applied in digital humanities. Currently, the basic principles of spatial data collection, handling, and analysis are generally used (see sections 2. Methods, 3. Map Design, and 4. Results). However, visual analytics (as defined in Keim et al. 2008) also seems promising.

The application of GIS in historical research (and religious studies research) is not completely new. Atlases of Havlíček, Klingorová, Lysák (2017), Kusendová (2011), or Majo, Kusendová (2015) are examples of cartographic products that cover this topic in Central Europe. Several projects work with digital cartography and GIS, for example, Pelagios (commons.pelagios.org), ORBIS (orbis.stanford. edu), or OpenAtlas (openatlas.eu). These projects focus mainly on data and are limited in their applied visualisation methods, which is often a restrictive factor in external use of the presented datasets (Mertel, Stachoň, Glomb 2016; Kubíček, Šašinka, Stachoň 2014). Examples of GIS analysis in the study of religions are Larsen, Benzek (2016) and Glomb et al. (2018). 
Research hypotheses and theories in religious studies are often too general and applied to a whole region without considering the spatial distribution of the phenomena under study. The aim of this study is to demonstrate a new analytical method mainly for researchers dealing with historical data about religions and offers better options for validating theories in the relevant space.

\subsection{Case studies}

The presented case studies were selected according to the scientific focus of the GEHIR project mentioned above. Each case study has its own research hypothesis presented below.

Case study 1 (CS1) - Mithraism: Mithraism was one of the many religious cults that proliferated in the society of the Roman Empire. The evidence of its existence begins to appear, rather abruptly, in historical sources in the last quarter of the first century CE. Mithraism especially flourished during the second and third centuries $C E$ and disappeared in the first half of the fifth century CE after the Christianisation of the Roman Empire. Although the exact scenario of Mithraic origins remains unknown (e.g. Chalupa 2016), evidence exists for strong ties between Mithraism and the Roman military (Daniels 1975, but cf. Gordon 2009). Roman soldiers were very clearly members of the cult, and numerous Mithraic communities can be found in close proximity to Roman legionary fortresses. Although this hypothesis seems plausible from a macro-perspective, it would be relevant to investigate whether these ties between Mithraic evidence and Roman legionary fortresses are spatially homogeneous or whether there were variations in the regions of the Roman Empire.

Case study 2 (CS2) - Egyptian gods: Early in the Ptolemaic era (ca 305-167 BCE), Egyptian cults spread successfully to the ports of the ancient Mediterranean and subsequently to the mainland (e.g. Bricault 2004, 2013; Dunand 1980). The goddess Isis and her divine husband Sarapis became the most popular Egyptian deities in the ancient Mediterranean. However, their cult outside Egypt was often accompanied by artefacts referencing other Egyptian deities such as Osiris (also brother/husband of Isis), Anubis, Apis or Horus. This group of deities is often referred to as the Isiac cults in academic discussion. However, a question remains whether the spread of these cults was coherent or whether some of these deities were represented more dominantly.

Case study 3 (CS3) - Church buildings: This study focused on the period of the third and fourth centuries CE. During this time, Christianity established itself in most urban centres of the Roman Empire. As we know from references in early Christian texts, Christianity flourished particularly well in certain locations where Christians erected their own religious buildings. Despite that information about 
the erection, use and destruction of church buildings is often based on literary evidence, this information is critically important, because it tends to be less disposed to idealisation than information about the numbers of Christians at certain locations (cf. Trombley 2006, Ehrman 2018, pp. 160-177). Although in the previous period of the first and second centuries CE the formative spread of Christianity was mainly located in the region of Syria-Palestine as a primary centre, during the third and fourth centuries CE the importance of Syria-Palestine decreased and more secondary centres emerged (cf. Tabbernee 2014). The analysis of spatiotemporal distribution of church buildings can demonstrate the existence of these secondary centres and assist in localising them.

\subsection{Methodology}

The aim in this paper is to effectively apply spatiotemporal visual analytic methods to the case studies described above. The application of these methods in any discipline (in this case religious studies) is also strongly encouraged by the commission on Visual Analytics of International Cartographic Association (ICA).

We propose an analytical tool that can visualise historical phenomena that emphasises uncertainties and can assist in answering hypotheses through the potential of visual analysis. This would permit better understanding of the patterns in datasets and help describe and communicate the studied historical processes. The process of designing the tool comprised several steps involving data collection and management, designing the application and selecting and implementing the method of cartographic visualisation. As a pilot study, special attention was given to selecting the proper methods of visualisation.

\section{Methods}

\subsection{Programming Environment (Software)}

Because the need for options in map interaction is increased with the analytical purpose of cartographic visualisations (MacEachren, Kraak 1997), we decided to create an interactive web application. This form allows functions such as zoom, pan, manipulation with layers or interaction with the visualisation method itself to be performed. All these functions can enhance the expressiveness of cartographic visualisations and their potential in data exploration (Andrienko, Andrienko 1999).

The core was created in the JavaScript programming language using development tools such as the babel compiler (babeljs.io) and webpack module bundler (webpack.github.io). The frontend was then implemented in the React library 
(facebook.github.io/react/), while state management was designed with the help of a custom MobX system (mobx.js.org). The cartographic visualisation was then created in the Leaflet web-mapping library (leafletjs.com) along with its plugins and extensions (github.com/PaulLeCam/react-leaflet, github.com/Leaflet/Leaflet. markercluster). The application was deployed at the website gehir.phil.muni.cz/ map. The source code is located at the GitHub versioning repository system (github. com/adammertel/gehir-mapapp). For the purpose of sharing the created datasets, a new blogpost on the GEHIR project page (gehir.phil.muni.cz) was created and the data were bound with the live URL link to the FTP repository.

\subsection{Data}

The datasets used in the application are described in the following section for each case study. They are available at the project's blogpost (gehir.phil.muni.cz/blog/ index.php?controller=post\&action=view\&id_post=9).

CS1 Mithraism: To address the hypotheses of this case study, two datasets were constructed. The first dataset was a list of 83 Roman military camps obtained from Bishop (2013). This publication consists of comprehensive information concerning each camp, including their precise geographic localisations. The main source for the second dataset was a corpus of 222 Mithraic archaeological evidence (Vermaseren 1956-1960) supplemented by Clauss $(1992,2012)$ and other relevant archaeological reports. To categorise the certainty of locations, a scale with three categories was created:

- Definitive - both archaeological evidence and the architectonic characteristics of the structural remains attest the presence of the cult.

- Probable - (1) the architectonic characteristics of structural remains are consistent with a Mithraeum; however, no supporting evidence confirming its Mithraic character was found; (2) or the presence of a Mithraeum is indicated only by an inscription mentioning its dedication, renovation, etc.

- Dubious - the place had been likely incorrectly interpreted as Mithraic in the past.

CS2 Egyptian gods: The input dataset for this case study was a list of 38 temples and 125 artefacts obtained from Bricault (2005). The data were prefiltered to contain only the places dated to the third century BCE. Also, because only two major deities in the dataset could show any significant spatial trend, all other deities were recategorized into one group called "other deities".

CS3 Church Buildings: The dataset was based on our geocoding of the textually presented data from MacMullen (2009, Appendix: Churches Built before 400, 
pp. 117-141) and offers a comprehensive list of spatiotemporal characteristics of 215 church buildings that existed in the first four centuries CE. The data were based on both literary and archaeological records.

\subsection{Visualisation methods}

To answer the hypotheses, a different visualisation method was selected for each case study:

- CS1 - Regular Grid Cluster

- CS2 - Gradual Segment Charts

- CS3 - Regionalisation

These methods are not completely unique to or innovative in cartography, but their implementation and use in religious studies is rare. Because the web environment enables users to interact with cartographic visualisations, all the selected methods were designed with this option, while the output was calculated on the fly after each new user input.

\subsubsection{Regular Grid Cluster}

One of the most commonly used examples of spatial visual analysis is the presentation of data that supports the potential to observe the spatial correlation of two specific datasets.

In this case, an extended grid-based visualisation method was used despite that it is primarily more suitable for displaying single-phenomenon datasets

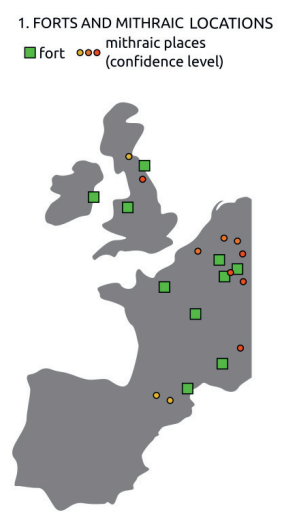

2. GRID CONSTRUCTION

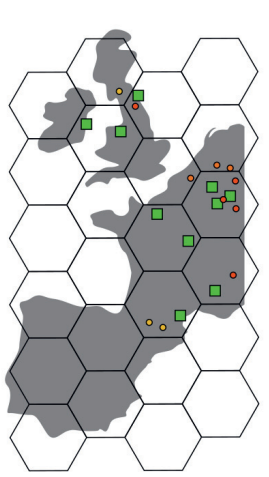

3. COLOURED CELLS BASED
ON THE NUMBER OF FORTS

$\square \square$ number of forts in each cell

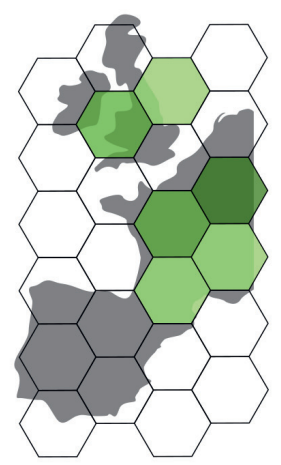

4. MARKERS TO INDICATE AGGREGATE MITHRAIC LOCATIONS

- number of mithraic places ○०० average confidence level

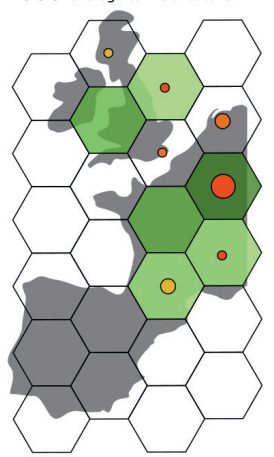

Fig. 1 - Visualisation of the Regular Grid Cluster method used for the Mithraism case study (CS1) 
(Andrienko, Andrienko, Denisovich 2004). Superimposing more datasets is a challenge in this type of visualisation (Carr, Olsen, White 1992). The notion behind extending the method is to allow aggregates to be represented in different graphical ways, for example, as a fill for the grid cell or as the size of a cell-centred mark. The graphical variables can also be used to visualise different properties of the aggregate, not only the number of members (e.g. maximum value, number of members with a value less than $x$, Andrienko, Andrienko 2006). Considering these ideas, two different datasets can be visualised on the same map while emphasising specific parameters to support the visual analysis (Fig. 1). This method was applied from the library Leaflet.RegularGridCluster (github.com/adammertel/ Leaflet.RegularGridCluster). In CS1, the shape of the cell is hexagonal (a hexagonal cell shape was selected because the centres of each cell are the same distance from each other), the colour intensity of the cell represents the number of aggregated forts in each cell and the centred marker indicates Mithraic places in each cell.

\subsubsection{Gradual Segment Charts}

From a statistical point of view, the dataset of temples and artefacts in case study CS2 has a compositional character - each item could belong to one or more deities. And if, for example, a temple was attributed to two deities, the effect of each deity on the neighbourhood was limited (50\%). The second factor is distance, and the impact of each temple decreased as the distance from the temple increased.

A common way of visualising compositional data in cartography is to use pie charts placed on a map as symbols. For the purpose of depicting phenomena in a continuous space and then following the trends in this space, customised, partly-opaque pie charts were adapted (Fig. 2). This transparency increases as the distance from the temple or artefact increases. This method was implemented as
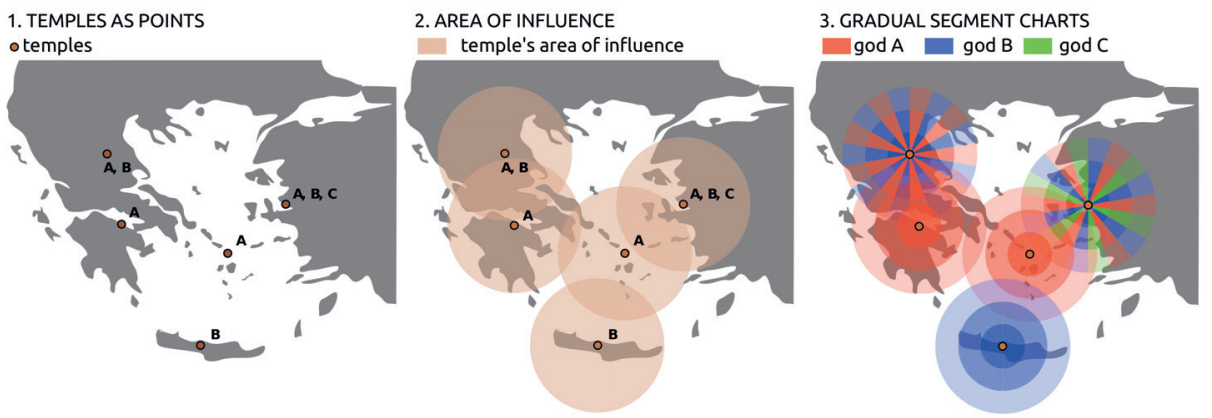

Fig. 2 - Visualisation of the Gradual Segment Charts method used in the Egyptian gods case study (CS2) 
an open-source Leaflet plugin called leaflet-segment-charts. The code is stored as a GitHub repository (github.com/adammertel/leaflet-segments-charts). When initialising the segments charts, parameters such as angle, segment colour and opacity decrease coefficient can be selected. It was also crucial to implement a colour blending technique that defined how the overlaid colours would interact (so that the top colour would not be preferred).

In the interactive part of the legend, two sliders were added so that the maximum segment range for artefacts and temples could be changed. Ternary diagrams were adapted in order to depict references to deities. These are ideal ways of visualising the attributional space of a compositional dataset (Pawlowsky-Glahn, Egozcue 2006).

\subsubsection{Regionalisation}

To improve the analytical potential, the CS3 map combined the church dataset with a proxy layer of social activity - a layer of important transportation nodes extracted from the popular ORBIS project (orbis.stanford.edu). To define the spatial impact of each node, a process for constructing regions was needed. According to Guo and Wang (2011), the point-pattern type of dataset allows this transformation. One way of creating these regions is using a method called Thiessen polygons, which is described in, for example, Okabe et al. (2000). This allowed the whole area of Roman Empire to be divided into non-overlapping regions, each defining the spatial surroundings of a single node.

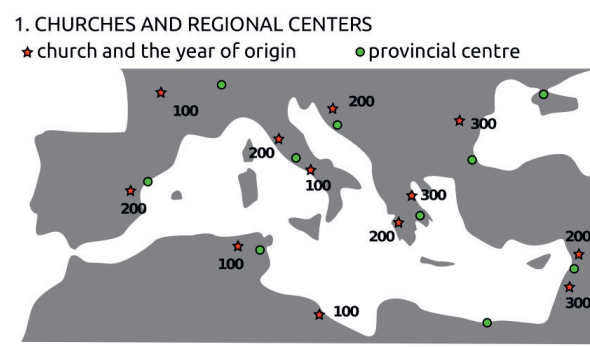

3. CREATING REGIONS FOR PROVINCIAN CENTERS (THIESSEN POLYGONS)

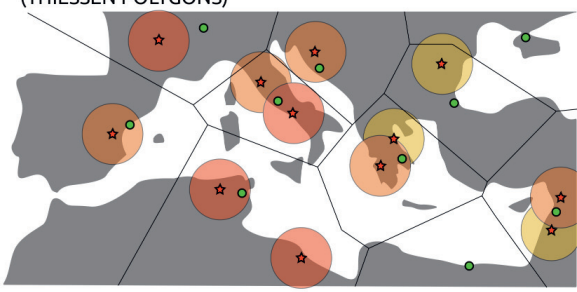

2. BUFFERING CHURCHES

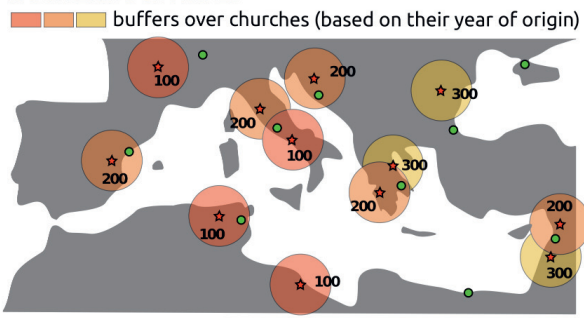

4. ASSIGNING VALUES TO REGIONS

$\square \square \square$ oldest church with the influence on region

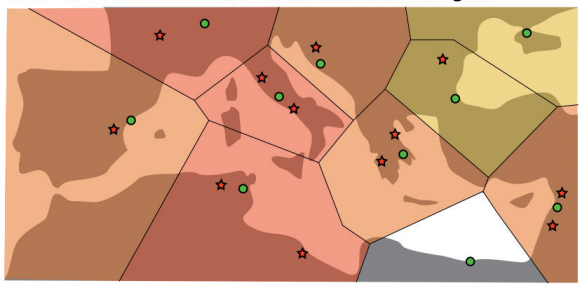

Fig. 3 - Visualisation of the Regionalisation method used for the Church buildings case study (CS3) 
To display the dynamics of a phenomenon, the church dataset was categorized into three time periods: before $313 \mathrm{CE}$, before $350 \mathrm{CE}$ and after $350 \mathrm{CE}$. In the next step of the analysis, radii were created around churches for each time period to merge the output. The distance of this radius is defined by the user and the output layer is processed on the fly with the turf.js (turfjs.org) library.

These radii are then merged according to their temporal value, and the intersecting regions of these unions are checked. Each region then takes the colour corresponding to the intersecting radius of the oldest church group. The entire process is shown in Figure 3. For comparison, a second mode without regions was added to this map to visualise unions of radii with the same temporal value.

\section{Map design}

\subsection{Application design}

The application was designed with a map-centred approach so that the map itself stores and transfers information and supports visual observation (e.g. Jankowski, Andrienko, Andrienko, 2001). The application has two side panels:

- The layer control panel is located at the top-right, its function being to provide options to change the visualised case study's base layer or toggle additional thematic layers.

- The Map legend is located at the bottom of the window and divided into two sections:

- The interactive section comprises input elements (e.g. sliders and check boxes) that allow the user to customise this visualisation method. Whenever an input is changed, new values are dynamically calculated, and the map is redrawn on the fly.

- The non-interactive section is essentially the legend itself. It depicts all the symbols used on the map. This section is redrawn whenever the map changes zoom-level or the topic is changed.

Both side panels overlay the map with an opacity of 0.9 , which allows the user to read the content but still maintains the application's map-like qualities. The colour scheme is simple and based on the colours used on the GEHIR webpage (dark grey \#666, white \#fff, and red \#74e3c).

Colours optimised for colour-blind users were obtained from the ColorBrewer 2 application (colorbrewer2.org) and used in the cartographic visualisations. Open Sans was selected as a font for two reasons. First, it was used as a font on the GEHIR web page, and second, it is an easily legible and widely used font on computer (mobile phone, tablet) displays and suitable for cartographic visualisation. 
The application was implemented with an interactive design so that it could be displayed on mobile phones or tablets.

\subsection{Base maps and auxiliary thematic layers}

A variety of available base maps can be added to the interactive web map. For this study, these were selected according to thematic relevance and to provide a broader range of options for use:

- AWMC (awmc.unc.edu)

- Digital Atlas of the Roman Empire (dare.ht.lu.se)

- Open Street Maps (openstreetmap.org)

- WorldImagery ESRI (arcgis.com)

The listed base maps were then customised to be less conspicuous and work better with the extensive thematic layers. Customisation was done using CSS3 filters in which colours were modified for less contrast and saturation. To support additional exploratory options, auxiliary thematic layers were added to the map. These are mainly datasets stored in various form (e.g. WMS, physical file) that may be relevant to a user's interests, for example, the extent of the Roman Empire, transport network of the Roman Empire or the borders of modern countries.

\subsection{Map functionality}

Interactive web environments provide new options for extending the functionality of cartographic visualisations. Maps can be restricted to a defined extent and zoom levels keep users focused on their tasks. Users can also pan and zoom, select layers and display detailed information. The visualisation itself and the legend are dynamic and depend on the zoom level.

\subsection{Browser compatibility}

The application was developed and tested in the Chrome browser. Some (less frequently used and older) browsers may have problems with certain functional features. 


\section{Results}

\subsection{Interpretation}

This section summarises and evaluates the given objectives and analytical possibilities of the application. Answers to the hypotheses proposed in Section 1.2 are provided, followed by a short interpretation.

CS1 Mithraism: According to the visual analysis, the original hypothesis that military forts were spatially correlated with places of Mithraic evidence could be assumed valid only in specific regions of the Roman Empire. It would therefore be interesting for researchers to look at those places in future studies. For example, with bigger cell sizes $(>7,000 \mathrm{~km})$, overlaid layers of forts and Mithraic evidence in the Limes Romanus region could be seen, especially in the basin of the Danube and the Rhine.

CS2 Egyptian gods: The presented visualisation method gave an overall view of dissemination throughout the studied region. The method allowed users to observe that the worship of different Egyptian deities in the Isiac family was spatially coherent. However, there were minor exceptions (e.g. the cult of Serapis was more active on the coast of modern south-west Turkey, while the cult of Isis was more active in modern Greece. However, in general and based on this map, we can affirm the spatial interconnection of Egyptian deities in the Mediterranean that would imply cooperation more than concurrency. A similar idea is also presented in the literature, for example, Dunand (1973).

CS3 Church Buildings: Interacting with the radius slider and exploring how the outcome changed led to the conclusion that Christian communities did not spread in a completely regular way from East to West. The spatiotemporal visual analysis indicated several possible secondary centres that played a crucial role in the spreading dynamics of Christianity during the period of the third and fourth centuries CE. This result agrees with the theory of Tabbernee (2014).

\subsection{Evaluation and Limitations of the Method}

To evaluate the designed interactive visualisation methods, interpretations from experts (Section 4.1.) were supplemented with qualitative insight from a technical and geographical point of view.

\subsubsection{Regular Grid Cluster}

After superimposing additional marker symbols on each cell, this method becomes suitable even for multiple datasets; moreover, it emphasises their mutual 
correlation. From a specific zoom level, the visualisation method changes, and each feature is presented with a circular map symbol. This symbol is then clickable so that individual objects can be inspected. One disadvantage of this method is the general problem of aggregation (described, for example, in Andrienko, Andrienko, 2006) in that the new representation of aggregated data could be improper or misleading. For example, a selected middle value may not fit the data distribution or could conceal an outlier or summing the values in the neighbourhood may change the spatial distribution pattern. As we saw in our case study, the option to change the cell size interactively in the visual analytical tools is crucial, as the correlation between datasets could vary between different grid cell sizes. Another problem is in the geographical distortion of the bins. It is unavoidable but should not be ignored, mainly in the case of smaller map scales (Battersby, Strebe, Finn 2017).

\subsubsection{Gradual Segment Charts}

The advantage of the gradual segment chart method is in displaying spatial patterns for proportional datasets. It covers the space with colour variations that represent the intensity of each category of the investigated phenomena. This method is based on visual impression - emphasis is placed on global pattern identification while reconstruction at the level of single objects is suppressed. To identify single locations, circle markers are displayed over the segment charts. These can be clicked on to open a tooltip with a description. The limitation of this method is in the low maximum number of categories and potential problems in visual perception that affect the possibility of distinguishing selected colour variations.

\subsubsection{Regionalisation}

The process of regionalisation in geoinformatics presents (besides, for example, the regular grid method presented in CS1) another way of aggregating point data. Instead of grouping elements into regularly-shaped bins, this method adapts the idea of dividing the space into more natural areas. In this case, these regions were created from a list of transportation network nodes that were adapted to polygons using the method of Thiessen polygons. These regions then are not only useful for visualisation but also support a statistical analysis of phenomena (Illian et al. 2008). Given the nature of this method, finding suitable sources for creating regions relevant to the dataset and corresponding to the analysed phenomenon is crucial, ideally splitting the space consistently. In other cases, the visualisation of regions could provide a false cartographic outcome.

A specific issue in this study then is the method of creating regions from centres. An interesting alternative to Thiessen Polygons might be constructing those regions according to the transportation environmental model. Another 
possible extension would be to visualise how much of the region is covered by the merged layer of buffers of the specific time period. For example, a region only slightly covered by the radius would be opaquer than a region fully covered by the radius.

The methods described are considered an experimental application that emphasises innovation and simple adaptability. This approach provided options for extending the use of datasets and customising studies about religions. As these methods have not been not broadly examined in geographic research (but are built on validated theories), it is not easy to compare them with other methods or to state whether they fit ideally in given situations. However, the results of this paper show that the methods used can effectively visually communicate the displayed datasets and helped answer the given research questions.

The created datasets were stored and handled in GeoJSON format, which also has some issues. Although it is human-readable, standardised and easy-to-use in web application form of storing complex spatial datasets (Butler et al. 2016), its file size is also larger than other data formats. This size limits the number of objects and their attributes that can be handled within the application. One potential, robust method could be to build a database with a server-side API.

\section{Discussion and conclusions}

One of the potential outcomes of GIS is spatial analysis that represents the notion of interactive, less publicly oriented geographic visualisations that allow the unknown to be studied (MacEachren, Kraak 1997). As some historians currently use maps mainly for visualisation purposes, this study opens the discussion of a possible shift in promoting maps to a form that could potentially answer research hypotheses. To investigate this assumption, an interactive web application was created. Three visualisation methods based on the hypotheses and datasets defined by three case studies were then adopted. The visual outcomes of those maps were interpreted, and emphasis was given to the new information obtained from the visual analysis according to the given hypotheses. These methods were then evaluated from a technical and geographical point of view and their limitations were identified.

In summary, it could be said that new knowledge gained from spatial visual analyses is valuable for further research. Experts in the study of religions were able to look at the problem from a different perspective and thus better understand these complex phenomena. The former general hypotheses were spatially atomised, and their validity was inspected in each region. The interactive environment was crucial in opening up potential methods (filtering, focusing, identification) that allowed better options for handling input data. The use of geographic visual 
analysis in research is limited, however, as the knowledge obtained is often based on a visual impression. Alternatives method for testing the hypotheses would be using geostatistical methods. These would allow results to be quantified and also provide the significance of those values. The method presented in this paper though could be used for the purpose of initial data exploration before any geostatistical analysis or as a more advanced way of visualising and presenting data to the public. Therefore, both geographical visual analysis and geostatistical analysis therefore complement each other and can be used in the same workflow. Another outcome of this study was the implementation of the three mentioned methods. The code itself is stored in a GitHub repository (github.com/adammertel/ gehir-mapapp) and the application is uploaded at gehir.phil.muni.cz/map. The availability of the designed tool may assist in promoting the use of geographic methods in various social sciences.

\section{References}

ANDRIENKO, G.L., ANDRIENKO, N.V. (1999): Interactive maps for visual data exploration. International Journal of Geographical Information Science, 13, 4, 355-374.

ANDRIENKO, G.L., ANDRIENKO, N.V., DENISOVICH, I. (2004): Dynamic aggregation on grids for interactive analysis of multidimensional spatial information. Lecture Notes in Proceedings AGILE, 207-212.

ANDRIENKO, N.V., ANDRIENKO, G.L. (2006): Exploratory analysis of spatial and temporal data: a systematic approach. Springer Science \& Business Media.

BATTERSBY, S.E., STREBE, D.D., FINN, M.P. (2017): Shapes on a plane: Evaluating the impact of projection distortion on spatial binning. Cartography and Geographic Information Science, $44,5,410-421$.

BERRY, D.M. (2012): Understanding digital humanities. Palgrave Macmillan, London.

BISHOP, M.C. (2013): Handbook to Roman Legionary Fortresses. Pen and Sword.

BODENHAMER, D.J., CORRIGAN, J., HARRIS, T.M., eds. (2010): The Spatial Humanities: GIS and the Future of Humanities Scholarship. Indiana University Press.

BRICAULT, L. (2004): La diffusion isiaque: une esquisse. Fremdheit-Eigenheit. Ägypten, Griechenland Und Rom. Austausch Und Verständnis, 548-556.

BRICAULT, L. (2005): Recueil des inscriptions concernant les cultes isiaques (RICIS). Mémoires de l'Académie des Inscriptions et Belles-Lettres.

BRICAULT, L. (2013): Les cultes isiaques dans le monde gréco-romain. Editions Belles Lettres. BUTLER, H., DALY, M., DOYLE, A., GILLIES, S., HAGEN, S., SCHAUB, T. (2016): The geojson format (No. RFC 7946).

CARR, D.B., OLSEN, A.R., WHITE, D. (1992): Hexagon mosaic maps for display of univariate and bivariate geographical data. Cartography and Geographic Information Systems, 19, 4, 228-236.

CHALUPA, A. (2016): The origins of the Roman cult of Mithras in the light of new evidence and interpretations: the current state of affairs. Religio, 24, 1, 65-96.

CLAUSS, M. (1992): Cultores Mithrae.: Die Anhängerschaft des Mithras-Kultes, 10, Franz Steiner Verlag. 
CLAUSS, M. (2012): Mithras: Kult und Mysterium. Darmstadt - Mainz: Philipp von Zabern.

DANIELS, C. (1975): The role of the Roman army in the spread and practice of Mithraism. In: Hinnels, J.R. (ed.): Proceedings of the First International Congress of Mithraic Studies, 2, 249-274.

DUNAND, F. (1973): Le culte d'Isis dans le bassin oriental de la Méditerranée, 26, Brill.

DUNAND, F. (1980): Cultes égyptiens hors d'Égypte: essai d'analyse des conditions de leur diffusion. Les Belles Lettres.

EHRMAN, B.D. (2018): The Triumph of Christianity: How a Forbidden Religion Swept the World. New York: Simon \& Schuster.

GLOMB, T., MERTEL, A., POSPÍŠIL, Z., STACHOŇ, Z., CHALUPA, A. (2018): Ptolemaic military operations were a dominant factor in the spread of Egyptian cults across the early Hellenistic Aegean Sea. PloS one, 13, 3, e0193786.

GREGORY, I.N., GEDDES, A., eds. (2014): Toward spatial humanities: Historical GIS and spatial history. Indiana University Press.

GOLD, M.K. (2012): Debates in the digital humanities. University of Minnesota Press.

GORDON, R.L. (2009): The Roman army and the cult of Mithras: a critical view. L'armée romaine et la religion sous le haut-empire romain. Lyons, 379-423.

GUO, D., WANG, H. (2011): Automatic region building for spatial analysis. Transactions in GIS, $15,29-45$.

HAVLÍČEK, T., KLINGOROVÁ, L., LYSÁK, J. (2017): Atlas náboženství Česka. Karolinum, Praha.

HAYLES, N.K. (2012): How we think: Transforming power and digital technologies. In Understanding digital humanities. Palgrave Macmillan, London, 42-66.

ILLIAN, J., PENTTINEN, A., STOYAN, H., STOYAN, D. (2008): Statistical analysis and modelling of spatial point patterns. John Wiley \& Sons.

JANKOWSKI, P., ANDRIENKO, N.V., ANDRIENKO, G.L. (2001): Map-centred exploratory approach to multiple criteria spatial decision making. International Journal of Geographical Information Science, 15, 2, 101-127.

KEIM, D., ANDRIENKO, G.L., FEKETE, J.D., GÖRG, C., KOHLHAMMER, J., MELANÇON, G. (2008): Visual analytics: Definition, process, and challenges. In Information visualization, Springer, Berlin, Heidelberg, 154-175.

KUBÍČEK, P., ŠAŠINKA, Č., STACHOŇ, Z. (2014): Selected cognitive issues of positional uncertainty in geographical data, Geografie, 119, 1, 67-90.

KUSENDOVÁ, D. (2011): Historický atlas evanjelickej cirkvi a. v. na Slovensku. Tranoscius, Liptovský Mikuláš.

LARSEN, L., BENZEK, S. (2016): Min(d)ing the gaps: Digital refractions of ancient texts. Ancient Worlds in Digital Culture, 128-147.

MACEACHREN, A.M., KRAAK, M.J. (1997): Exploratory cartographic visualization: advancing the agenda.

MACMULLEN, R. (2009): The second church: popular Christianity AD 200-400, Society of Biblical Lit., 1.

MAJO, J., KUSENDOVÁ, D. (2015): Náboženský atlas Slovenska. Dajama.

MERTEL, A., STACHOŇ, Z., GLOMB, T. (2016): GIS for Religious Studies. In: Bandrova, T., Konečný, M. (eds.): Proceedings, $6^{\text {th }}$ International Conference on Cartography and GIS, Sofia: Bulgarian Cartographic Association, 1, 2, 259-265.

OKABE, A., BOOTS, B., SUGIHARA, K., CHIU, S.N. (2000): Spatial Tessellations: Concepts and applications of Voronoi diagrams, John Wiley \& Sons. Chichester, UK. 
PAWLOWSKY-GLAHN, V., EGOZCUE, J.J. (2006): Compositional data and their analysis: an introduction. In: Buccianti, A., Mateu-Figueras, G., Pawlowsky-Glahn, V. (eds.): Compositional data and their analysis in the Geosciences: From Theory to Practice. Geological Society, London, Special Publications, 264, 1, 1-10.

PRESNER, T. (2010). Digital Humanities 2.0: a report on knowledge.

SCHREIBMAN, S., SIEMENS, R., UNSWORTH, J. (2015): A new companion to digital humanities. John Wiley \& Sons.

TABBERNEE, W., ed. (2014): Early Christianity in Contexts: An Exploration across Cultures and Continents. Grand Rapids, MI: Baker Academic.

TROMBLEY, F. (2006): Overview: The geographical spread of Christianity. In: Mitchell, M., Young, F. (eds.): The Cambridge History of Christianity. Origins to Constantine, 1, Cambridge, UK: Cambridge University Press, 302-313.

VERMASEREN, M.J. (1956-1960): Corpus Inscriptionum et Monumentorum Religionis Mithriacae, 2.

\section{Supplemental online material:}

http://gehir.phil.muni.cz/blog/index.php?controller=post\&action=view\&id_post=9

http://gehir.phil.muni.cz/image/paper/regions.pdf

http://gehir.phil.muni.cz/image/paper/grid.pdf

http://gehir.phil.muni.cz/image/paper/temples.pdf

\section{ACKNOWLEDGMENTS}

This work was supported by the project GEHIR "A Generative Historiography of the Ancient Mediterranean, ID MUNI/M/1867/2014" and by the Specific Research project "MUNI/A/1576/2018, Complex research of the geographical environment of the planet Earth", both funded by Masaryk University. 